\title{
Nordiques
}

35 | 2018

Tove Jansson : Par delà les genres. Pratiques

linguistiques dans le Norden du XXIe siècle : Quels

enjeux sociaux?

\section{Translanguaging Practices in Bilingual Adolescents' Conversations in Haparanda, Stockholm and Helsinki}

Jaana Kolu

\section{OpenEdition}

\section{Journals}

Electronic version

URL: https://journals.openedition.org/nordiques/1016

ISSN: $2777-8479$

Publisher:

Association Norden, Bibliothèque de Caen la mer

Printed version

Date of publication: 1 May 2018

Number of pages: 135-153

ISBN: 979-1-0959140-1-3

ISSN: $1761-7677$

Electronic reference

Jaana Kolu, "Translanguaging Practices in Bilingual Adolescents' Conversations in Haparanda,

Stockholm and Helsinki", Nordiques [Online], 35 | 2018, Online since 02 February 2021, connection on

06 October 2021. URL: http://journals.openedition.org/nordiques/1016 


\section{Translanguaging Practices in Bilingual Adolescents' Conversations in Haparanda, Stockholm and Helsinki}

RÉSUMÉ

Jaana Kolu ${ }^{*}$

Cet article se propose de décrire et de comparer les pratiques langagières d'adolescents bilingues suédois-finnois originaires de Haparanda, Stockholm et Helsinki dans trois situations sociolinguistiques différentes entre 2014 et 2017. Nous analysons ces pratiques par le biais $d u$ "translanguaging ", un courant théorique qui se définit comme l'utilisation simultanée de ressources linguistiques diverses en situation informelle. Une approche translangagière présente l'avantage d'explorer l'utilisation et les fonctions de l'alternance de ressources en interaction plutôt que de se focaliser sur les langues en elles-mêmes. Une attention particulière est portée aux pratiques translangagières des jeunes bilingues originaires de Haparanda, une ville suédoise située au nord-est de la frontière avec la Finlande, en raison de la rareté des données dans cette zone pourtant connue pour son bilinguisme. Nous démontrons que les adolescents utilisent couramment et avec souplesse des ressources linguistiques diverses telles que le suédois et finnois "standard", l'anglais, le meänkieli ${ }^{1}$, les dialectes locaux ou encore l'argot des jeunes à des fins communicationnelles. Le contexte sociolinguistique joue un impact considérable pour comprendre l'utilisation de ces ressources.

ABSTRACT

This study examines the functions of translanguaging, i.e. the use of multiple linguistic resources in informal conversations among bilingual adolescents in three different sociolinguistic settings Haparanda, Stockholm and Helsinki. The focus is on bilingual young people's language in Haparanda, a Swedish town on the country's northeastern border with Finland. The language use of bilingual young people in Haparanda has rarely been studied, although there has been a Finnish-speaking population in northern Sweden for hundreds of years. The theoretical framework is found in the field of translanguaging, which explores bilingual language use and interactional practices rather than focuses on the languages themselves. The primary data from Haparanda (2014-2017) consists of close to twenty hours of video-and audio-recorded informal group and pair conversations. The data from Stockholm (2015-2016) and Helsinki (2014) was collected for comparison. The analysis of the collected data is qualitative. Similar patterns could be found in these three cities, but the language settings impact on adolescents' translanguaging. The study shows that speakers fluently and flexibly make use of their language resources for different communicative purposes, e.g. clarifications, quoting, referring to culturespecific items, expressing feelings and playing with languages. Not only are Standard Swedish and Finnish used in conversations, but so too are English, Meänkieli ${ }^{1}$, local dialectal features, youth slang and other language resources.

* Jaana Kolu, PhD, senior lecturer in Swedish at the University of Stockholm.

1 Meänkieli is the official name of the language "located close to the far northern dialects of Finnish spoken in the Swedish parts of the Torne Valley and its surroundings". L. Arola, N. Kunnas, B. Winsa, "Meänkieli in Sweden: An Overview of a Language in Contact", Working Papers in European Language Diversity, 6, 2015. 


\section{INTRODUCTION}

Translanguaging is still a developing umbrella term for people's use of languages bilingually in interactions $s^{2}$. Originally, translanguaging referred to a bilingual pedagogical practice used in a classroom, but today the term is used more broadly to refer to all kind of bilingual and multilingual interaction ${ }^{3}$. García considers translanguaging to be the normal mode of communication for bilingual people and concludes, "translanguagings are multiple discursive practices in which bilinguals engage in order to make sense of their bilingual worlds" 4 . García suggests that the translanguaging perspective takes a different position from traditional code-switching research, which has considered a bilingual's two languages to be two separate monolingual systems ${ }^{5}$. Instead of deciding which language to use in different social contexts, bilinguals and multilinguals select different features from their linguistic repertoire, when they communicate with each other ${ }^{6}$.

As the aim of this article is to describe bilingual communicative practices and adolescents' use of their language repertoires, translanguaging provides a relevant theoretical framework. Different language resources and multiple varieties like dialect and slang are understood as one multilingual repertoire from which interlocutors select features, like words, to communicate effectively ${ }^{7}$. Even though the names of particular languages or varieties, like Finnish and Swedish, are used in the analysis, it is bilingualism as a whole that is in focus, not the individual languages as separate systems.

The main focus of this study is on bilingual (in Finnish/Swedish) adolescents in Haparanda, in northern Sweden, on the border of Finland and Sweden. Those in the comparison groups are bilingual in Finnish and Swedish (or multilingual in Finnish, Swedish and English) and live in Stockholm and in Helsinki, two Nordic capitals. Making comparisons between translanguaging and communicative practices in the same pair of languages, Finnish and Swedish, in three different language settings, highlights the effects of sociolinguistic factors on translanguaging. We can find out if adolescents' interaction practices and their use of linguistic resources differ in the three different language environments.

2 Gwyn Lewis, Bryn Jones, Colin Baker, "Translanguaging: Origins and Development from School to Street and Beyond", Educational Research and Evaluation. An International Journal on Theory and Practice, Londres, Routledge, 2012, p. 641-654.

3 Ibid., p. 655-670.

4 Ofelia García, Bilingual Education in the 21: Century. A Global Perspective, Oxford, Wiley, 2009, p. 45 .

5 Ofelia García, "Theorizing translanguaging for educators", in Translanguaging. A CUNY-NYSIEB. Guide for educators, C. Celic and K. Seltzer (ed.), New York, CUNY-NYSIEB, The Graduate Center, The City University of New York, 2011, p. 1-6.

6 Ofelia García, Li Wei, Translanguaging. Language, Bilingualism and Education, Basingstoke, Palgrave Macmillan, 2014.

7 Ibid., p. 22. 
The research questions in this study are as follows:

1) What are the functions of translanguaging, i.e. what are the reasons for multiple language use in bilingual adolescents' interactions in Haparanda, Stockholm and Helsinki?

2) What are the similarities and differences between the language use and communicative practices of bilingual adolescents in Haparanda, Stockholm and Helsinki?

\section{RESEARCH SETTINGS}

Haparanda is a small town in a rural area in Tornedalen, on Sweden's northeastern border with Finland. It has approximately 10,000 inhabitants. Haparanda has been placed second in a list of municipalities with the highest proportion of people in the population with a foreign background in Sweden. According to Statistics Sweden (2017), over 50 percent of the inhabitants of Haparanda have a foreign background and over 80 percent of the population of Haparanda have some Finnish roots, i.e. at least one grandparent was born in Finland ${ }^{8}$. Approximately 40 percent of the population were born in Finland. Today (Standard) Finnish and Meänkieli are official minority languages in Tornedalen ${ }^{9}$ and local attitudes towards (Standard) Finnish and Meänkieli are positive ${ }^{10}$. As late as the 1960 's it was still forbidden to use Finnish in schools in Tornedalen ${ }^{11}$. Nowadays there is one Swedish-speaking junior high school in Haparanda and there are two bilingual junior high schools, in which pupils can choose bilingual tuition. All these three junior high schools participated in this study. Today an increasing number of pupils study Finnish as their L1 (First Language) and Swedish as L2 (Second Language), according to teachers at these three junior high schools. There is no official language registration in Sweden.

According to Statistics Sweden (SCB) Finns are the largest immigrant group in Sweden, with more than 150,000 born outside Sweden, and 550,000 second- or third-generation Sweden Finns ${ }^{12}$. Sweden Finns are a Finnish-speaking national minority and Finnish is an official minority language in Sweden. There are 450,000-500,000 Sweden Finns, approximately 47,000 of whom live in

8 Statistics Sweden. Available at: http://www.scb.se/hitta-statistik/statistik-efter-amne/befolkning/ befolkningens-sammansattning/befolkningsstatistik/pong/tabell-och-diagram/topplistor-kommuner/ andel-personer-med-utlandsk-bakgrund/2017 (Last visited September $20^{\text {th }} 2017$ ).

9 SOU 1997: 192. Betänkandet från Minoritetsspråkskommittén, Stockholm, Jordbruksdepartementet. SOU 1997: 193. Betänkandet från Minoritetsspråkskommittén, Stockholm, Jordbruksdepartementet.

10 Leena Huss, “We'll have to take it back!' Reclaiming Meänkieli in a Tornedalian school in Sweden”, in Transcending Monolingualism. Linguistic Revitalisation in Education, L. Huss, G. A. Camilleri and K. A. King (ed.), Lisse, Swets \& Zeitlinger, 2003, p. 225-240.

11 Nils-Erik Hansegård, Den norrbottenfinska språkfrågan, Uppsala, Uppsala universitet, 1990.

$12 \mathrm{https} / /$ nordic.businessinsider.com/swedens-foreign-born-population-is-nearly-17-millionpeople---finns-are-the-biggest-group-2017-3 (Last visited March 27 ${ }^{\text {th }} 2018$ ). 
Stockholm ${ }^{13}$. Today, Sweden Finns in Stockholm are a scattered minority, living in a multilingual reality ${ }^{14}$. There are three Sweden-Finnish junior high schools in Stockholm County, two of which participated in this study.

The population of Helsinki is today predominantly Finnish-speaking, but approximately 5,7 percent of the population are Swedish-speaking ${ }^{15}$. Helsinki has a population of 635,000 and Swedish is the mother tongue of about 36,000 inhabitants. The Swedish-speaking minority in practice often lives in an everyday bilingualism in bilingual families ${ }^{16}$. The influence of the Finnish language on the Swedish spoken in Helsinki shows in the number of loan words and code-switching, especially among adolescents ${ }^{17}$. Of the six Swedish junior high schools in Helsinki, one participated in this study.

\section{DATA, PARTICIPANTS AND METHODS}

\subsection{Data collection}

The primary data consists of close to twenty hours of video- and audio-recorded group and pair conversations. The data was collected in 2014-2017 among 13-15-year-old bilingual pupils at three junior high schools in Haparanda. Each of the twenty-five conversations continued for anything between fifteen minutes and one and a half hours. The first set of material for comparison consists of eight hours of video- and audio-recorded group conversations among 13-15-year-old bilingual pupils in two Sweden-Finnish junior high schools in Stockholm in 2015-2016. Each of the conversations lasted for between fifteen minutes and one and a half hours. The second set of material for comparison was collected in 2014 at a Swedish junior high school in Helsinki. It comprises about six hours of informal conversations between bilingual 13-15-year-olds. The seven group conversations in Helsinki lasted for between twenty minutes and one and a half hours.

All the recordings were made outside of the lessons and classroom. The participants could converse among themselves and be recorded during breaks

13 Minoritet.se http://www.minoritet.se/ (Last visited March 20 2018).

14 Annaliina Gynne, Languaging and Social Positioning in Multilingual School Practices. Studies of Sweden Finnish Middle School Years. Mälardalens högskola, Akademin för utbildning, kultur och kommunikation. Mälardalen Studies in Educational Sciences No. 26; J. Lainio, "Från finskt i Sverige till sverigefinnar och sverigefinska", in Nöd och lust. Sverige och Finland i samtid och i framtid, T. Hallberg. (ed.), Stockholm, Föreningen Norden. Föreningen Nordens årsbok, 2009, p. 142-143.

15 Statistics Finland. https://www.hel.fi/hel2/tietokeskus/julkaisut/pdf/17_06_28_Tilastoja_1_ Maki_Vuori.pdf (Last visited March 20 $0^{\text {th }}$ 2018).

16 Fjalar Finnäs, Finlandssvenskarna. En statistisk rapport, Helsingfors, Svenska Finlands folkting, 2012.

17 Leif Höckerstedt, "Helsingforssvenskan: vem är du?”, in Helsinki kieliyhteisönä, K. Juusela and K. Nisula (ed.), Helsingfors, Institutionen för finska språket och inhemsk litteratur vid Helsingfors universitet, 2006, p. 123-139. 
and lessons, but outside of the classroom, i.e. in separate school rooms. This was to make the conversation situation as undisturbed and natural as possible. The interlocutors were not told what language to use or what subjects to talk about, just to talk as normally as possible. The participants were told that the purpose of the study is to research their language use in interaction. The conversations turned out to cover such subjects as school, future plans, hobbies, leisure time, films, and music. Additionally, a questionnaire was used after the recording to assess the adolescents' language background. The participants' language backgrounds are presented briefly below.

\subsection{Participants}

A total of seventy-seven 13-15-year-olds participated in the video-recordings, forty-five in Haparanda, twenty-two in Stockholm and ten in Helsinki. Their mother tongues are shown in Table 1.

Table 1. Language backgrounds of the participants in Haparanda, Stockholm and Helsinki

\begin{tabular}{|l|c|c|c|c|}
\hline Site & $\begin{array}{c}\text { Total number } \\
\text { of participants } \\
\text { (N) }\end{array}$ & $\begin{array}{c}\text { Bilingual/ } \\
\text { Multilingual }\end{array}$ & $\begin{array}{c}\text { Finnish as the } \\
\text { mother tongue }\end{array}$ & $\begin{array}{c}\text { Swedish as the } \\
\text { mother tongue }\end{array}$ \\
$\begin{array}{l}\text { Haparanda } \\
\text { Stockholm }\end{array}$ & 45 & 15 & 27 & 3 \\
Helsinki & 22 & 5 & 12 & 5 \\
& 10 & 8 & 1 & 1
\end{tabular}

As Table 1 shows, twenty-seven of the forty-five pupils in Haparanda said in the questionnaire that Finnish was their mother tongue. Fifteen of the pupils considered themselves to be bilingual, and three pupils gave Swedish as their mother tongue.

Twelve of the twenty-two participants in Stockholm claimed that Finnish was their mother tongue. Four of them considered themselves to be bilingual in Finnish and Swedish, and one of them was multilingual in Finnish, Swedish and English. Five of the participants in Stockholm claimed that Swedish was their mother tongue.

Eight of the ten pupils who participated in the video-recorded conversations in Helsinki considered themselves to be bilingual. Seven of them said that they were bilingual in Finnish and Swedish and one was bilingual in Swedish and English. One considered Swedish to be her mother tongue and one had Finnish as her mother tongue. All of the participants were asked to suggest a pseudonym for themselves, and these are the names used in this paper. 


\subsection{Analysis}

The analysis of the recordings is qualitative. Examples from the data are given in a rough orthographic transcription and the transcripts contain only those features which are relevant for the analysis. In the examples, the different linguistic resources that come from different languages or varieties are marked: bold is used for Finnish and Meänkieli elements, underlining for Swedish elements, and italics are used for English and other foreign languages. Each speaker's turn begins on a new line and there is a free translation below each utterance. Code-switching from Finnish to Swedish in the same line in the transcription is marked after the translation with "(Finnish-Swedish)", and from Swedish to Finnish with "(Swedish-Finnish)". Backslash is used between the code-switching and translations from Finnish and Swedish and vice versa. The Leipzig glossing is used to make linguistic structures in code-switching transparent, e.g. praoamaan $\left(\right.$ Swedish word for 'train' + Finnish INFINITIVE MARKER) ${ }^{18}$. The conversations are analyzed from the viewpoint of the participants' translanguaging and the transcribed data is analyzed moment-by-moment in those sequences during which the adolescents translanguage, i.e., use their multiple language resources.

\section{Results: Translanguaging PRACTICES IN THE BILINGUAL ADOLESCENTS' CONVERSATIONS}

\subsection{Negotiation and co-constructing meaning}

In all of the conversations in Haparanda, Stockholm and Helsinki (20142017) there were at least small interruptions in the communication between the bilingual adolescents. These interruptions could be caused by a lack of understanding, or by different opinions as to what was the right word in the context, or the meaning of a word, for example. A lack of understanding and different opinions of the meanings of some words can probably partly be explained by individual language biographies, abilities and preferences. In the example (1) that follows, three bilingual adolescents, Lassi, Annina and Pia are talking about vehicles they have at home.

18 The Leipzig Glossing Rules: Conventions for interlinear morpheme-by-morpheme glosses, Leipzig, last change: May 31, 2015, https://www.eva.mpg.de/lingua/pdf/Glossing-Rules.pdf (Last visited March $20^{\text {th }} 2018$ ). 
(1) "kolme mitä" 'three what?"

\begin{tabular}{|l|l|}
\hline 1 Lassi: & $\begin{array}{l}\text { meillä on kolme krossia } \\
\text { 'we have three motocross bikes' } \\
\text { meillä ei oo yhtään } \\
\text { 'we haven't any' } \\
\text { meillä on- } \\
\text { 'we have-' } \\
\text { ja kaks peltoautoa- kolme peltoautoa } \\
\text { 'and two field cars- three field cars' } \\
\text { kolme mitä } \\
\text { 'three what?' } \\
\text { kolme peltoautoa }\end{array}$ \\
6 Lassi: & $\begin{array}{l}\text { 'olmree field cars' } \\
\text { 'tär det en sån där- }\end{array}$ \\
8 Pia: & $\begin{array}{l}\text { 'is it like-?' } \\
\text { dom bilar som man kör på ängen } \\
\text { 'those cars you drive in the field' } \\
\text { oj dom är ju kul /meillä oli pietarsaaressa semmonen } \\
\text { 'oh those are fun/we had one of those in pietarsaari' } \\
\text { (Swedish-Finnish) }\end{array}$ \\
\hline
\end{tabular}

In line 4, Lassi tells in Finnish that they have three field cars. Annina does not understand the meaning of the Finnish word peltoauto 'field car' and asks in Finnish, "kolme mitä", 'three what?'. In line 6, Lassi repeats the utterance in Finnish, "kolme peltoautoa", 'three field cars'. In line 7, Pia switches to Swedish and asks, "är det en sån där-", 'is it like-?'. Lassi explains the meaning of the word in Swedish, "dom bilar som man kör på ängen", 'those cars you drive in the field'. It is impossible to know why the interlocutors switch from Finnish to Swedish, but Lassi's explanation what the Finnish word peltoauto 'field car' means in Swedish, seems to convey Pia's understanding of the meaning of the word. This example shows that the participants can use flexibly their language resources for clarifications and for achieving and supporting mutual understanding.

There were several examples in the data where participants use metalanguage in the process of making meaning and gaining understanding. There does not generally appear to be important in which language the mutual understanding is achieved, what seems to be more important is the co-construction of mutual understanding. In the data from all three settings the bilinguals use a lot of metalanguage. As García suggests, "children translanguage constantly to co-construct meaning, to include others, and to mediate understandings". According to García, bilingual children 
tend to have metalinguistic skills that can contribute to mutual understanding in a group of interlocutors with different language profiles ${ }^{19}$.

\subsection{Referring to cultural phenomena and everyday objects in the surrounding society}

Although the bilingual interlocutors in Haparanda speak mainly Finnish with each other, they use Swedish words for school subjects, like idrott 'physical education', spanska 'Spanish', matte 'maths', $\underline{S O}$ 'social studies' and $\underline{\mathrm{NO}}$ 'natural science', even when they are otherwise speaking Finnish. This concerns all school topics. Nevertheless, no violation to Finnish syntax is occurred, i.e. the Swedish nouns and verbs are integrated into the morphosyntactic structure of Finnish. In the following utterance "äiti menee föräldramöteen" 'my mother is going/ to the parents' meeting' (Finnish-Swedish), the Swedish word föräldramöte is in the Finnish locative case, illative as it has the ending -(e)en, föräldramöteen (parents meeting + ILL $)^{20}$. In the sentence "me saahaan mennä praoamaan, 'we may go to /practical training' (Finnish-Swedish), the Swedish verb praoa has the Finnish infinitive marker - maan $^{21}$ : praoamaan (train + Finnish INFINITIVE MARKER).

The adolescents in Stockholm speak mainly Swedish with each other, but when they speak Finnish, they switch to Swedish words when they discuss school matters in the same way as the adolescents do in Haparanda. This is understandable considering that instruction is given mainly in Swedish and the Swedish curriculum is taught at the schools in Haparanda and in Stockholm: it is only natural that the pupils should use Swedish words for school subjects. Some of these words do not have any exact equivalent in Finnish, for example språkval 'language choice, i.e. optional language' and nationella 'nationwide exams'. The bilingual interlocutors in Haparanda also use Swedish words for figures, times, weekdays and months even when speaking Finnish, e.g. mää olin typ fem år då, 'I was/like five years old then' (Finnish-Swedish), kiva bussissa yksin istua fyra timmar, 'nice to sit in the bus alone/four hours' (Finnish-Swedish), meillähän loppuu tjugofem över, 'we will finish/twenty-five past' (Finnish-Swedish). This phenomenon was not found in the data from Stockholm.

In Helsinki the pupils speak mainly Swedish and sometimes use Finnish words for school subjects like kässä for 'crafts', or hissa for 'history', even though the instruction is given in Swedish in their Swedish-speaking school and the pupils

19 Ofelia García, "Theorizing translanguaging for educators", op. cit., p. 6.

20 See Jaana Kolu, "Onko suomen ja ruotsin koodinvaihdolla kielioppia? Substantiivien ja verbien taivutus Haaparannan, Tukholman ja Helsingin kaksikielisissä keskusteluissa”, Lähivertailuja, 26, 2016, p. 182-221. http://arhiiv.rakenduslingvistika.ee/ajakirjad/index.php/lahivordlusi/issue/view/LV26 (Last visited March $20^{\text {th }}$ 2018).

21 Ibid., p. 206. 
do not need to switch languages when they talk together about anything to do with school. Nevertheless, the Swedish-speaking school follows the Finnish school curriculum and the school subjects often have the same colloquial forms in Finnish and Swedish. In Helsinki Swedish- and Finnish-speaking adolescents share the same slang and colloquial vocabulary ${ }^{22}$.

The adolescents in all three settings also use their majority language resources when they refer to cultural phenomena and institutions in the language community outside of the school. For instance, the participants in Haparanda refer to aspects of Swedish society like långvård 'care of the elderly' and högskoleförberedande program 'higher education preparatory programme'. They also plan to apply for a summer job "kommunin kautta" 'via municipality + GEN' (SwedishFinnish). The Swedish word kommun is inflected in the Finnish genitive case. In Stockholm they use Swedish words like gym 'gym' and distriktmästerskap 'district championship' even when they are speaking Finnish, while the bilingual adolescents in Helsinki use Finnish words like lukio 'high school' and ripari 'confirmation camp' even though they are speaking Swedish. In Finland over 85 percent of 15 -year-olds go to confirmation classes, and confirmation camp can be considered a typical Finnish cultural phenomenon.

Everyday objects in the adolescents' conversations in Haparanda and in Stockholm also come from the majority language, i.e. Swedish: "ostin plåtburkin Ikeasta", 'I bought /a tin + Finnish ending for GEN/ in Ikea" (Finnish-Swedish). "mää saan ne sminkborstet", 'I get those make-up brushes + ACCUSATIVE PLURAL' (Finnish-Swedish). In Helsinki the role of the languages is reversed: "de far till Alepa och köper karkki”, 'they will go to Alepa and buy/candy' (SwedishFinnish), "vi har såna här ruisnappeja hemma", 'we have those/rye buttons (Finnish bread) +Finnish PARTITIVE PLURAL/ at home' (Swedish-FinnishSwedish). The embedded Finnish word ruisnappeja 'rye buttons' is inflected according to Finnish grammar, in partitive plural. The word is inflected as it would be inflected in the equivalent sentence in Finnish, i.e. the word in not integrated into the Swedish morphosyntax ${ }^{23}$.

In conclusion, the language settings impact on adolescents' translanguaging, i.e. their use of their language resources is related to the majority language inside and outside of the school and specific words used for referring to cultural phenomena and referents in the surroundings. As García suggests, "bilinguals usually have differentiated use and competence in the languages in which they translanguage, having had exposure to various language practices" 24 .

22 Svenska Litteratursällskapet (The Society of Swedish Literature in Finlamd), http://www.sls.fi/en/ node/1797 (Last visited March 20 $0^{\text {th }}$ 2018).

23 See Jaana Kolu, op. cit., p. 197.

24 Ofelia García, Bilingual Education in the $21^{\text {st }}$ Century, op. cit., p. 48. 


\subsection{Quotation in the original language}

What is common to all the three language settings is that the interlocutors quote other speakers' words in the original language that they have heard (or read). The language pair, Finnish and Swedish, have reverse roles in Haparanda/ Stockholm and Helsinki, which is probably caused by the different minority and majority roles in the society. For instance, TV channels are Swedish in Sweden and mainly Finnish in Finland ${ }^{25}$. The following example (2) is from Haparanda, where the participants are discussing the Swedish version of the TV-program Paradise hotel and Emma is talking about the latest episode. Emma starts off in Finnish, but she switches to Swedish when she quotes a person in the program. She tells about one of the participants in the program and about her reactions after winning 50,000 Swedish crowns (SEK). Emma uses the Finnish discourse marker vaan before quoting in Swedish, ihana ihminen se vaan jag tror jag fick blackout eller, 'lovely person she just/I think I got blackout' (Finnish-Swedish).

(2) “se vaan jag tror jag fick blackout" 'she just I think I got blackout'

\begin{tabular}{|l|l|}
\hline 01 Emma: & $\begin{array}{l}\text { mutta se sano (.) siis se alko itkeen raukka se on niin } \\
\text { 'but she said (.) then she started crying poor thing she is so' } \\
\text { ihana ihminen se vaan jag tror jag fick blackout eller } \\
\text { 'lovely person she just/I think I got blackout' (Finnish-Swedish) } \\
\text { eller nå:nting ja tälleen } \\
\text { 'or something and so' (Swedish-Finnish) }\end{array}$ \\
\hline
\end{tabular}

In one conversation from Helsinki, one of the participants stated that, according to the Finnish TV-guide, the program she was watching had a happy ending: "och sen onnellinen loppu det var ingen onnellinen loppu", 'and then the happy ending, there was no happy ending' (Swedish-Finnish). The speaker is probably referring to the original Finnish words in the TV -guide. In another conversation, adolescents in Helsinki refer to a famous Finnish rapper named Cheek. Cheek had had his last concert, which the two of the interlocutors had attended, and one of them quoted his words when he explained (in Finnish) the reasons why he needed a break: "som han själv sa han måste hengittää", 'as he said himself he has to breathe' (Swedish-Finnish).

\subsection{Translation, repetition and replacing}

The co-constructing of meaning in the adolescents' conversations often starts with an open question: "What is it (in Finnish or in Swedish)" or "How do you say it in Finnish or Swedish?" The participants in Haparanda and Stockholm more often search for translations of Swedish words into Finnish, e.g. "Mikä on repetition suomeksi?", 'what is/revision/in Finnish', “mitä on kräsen?", 'what is/

25 One national channel in Finland broadcast in Swedish. 
picky/ (in Finnish)', while those in Helsinki more often search for Swedish words. Sometimes they turn to English: "han har bra kindmuskler inte kindmuskler utan kindben jag vet inte om man säger så- cheekbones?”, 'he has good cheek muscles not cheek muscles but cheekbones I don't know if you can say so-/cheekbones' (Swedish-English).

According to García translations are the easiest way to translanguage ${ }^{26}$. In all three settings in this study the adolescents constantly use translation and repetition for clarification, i.e. they repeat the same utterance in both of the languages, Finnish and Swedish, raukka lapsi stackars barn, 'poor child' (Finnish-Swedish),

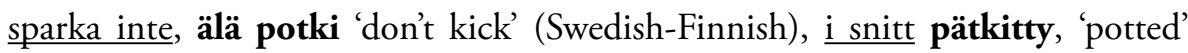
(Swedish-Finnish). Pardane and Kisno argue that when a bilingual speaker wants to make sure that he/she will be understood, he/she can use both of the languages and say the same utterance repeatedly ${ }^{27}$. On the other hand, we found that translations and repetitions are common also in situations in which there are no evident problems with understanding. Translations and repetitions seem therefore to be a communication practice bilinguals engage in, although there is not always a clear communicative need for that. Thus, we assume that translations and repetitions can be seen as a communicative strategy that bilinguals use to signal their bilingual identity and a sense of togetherness with other bilinguals.

If the speakers cannot find the right word in one language, they use the equivalent in the other language. In example (3) below from Stockholm, Hanna uses the wrong Finnish word in the context. She says tunnus 'symbol' instead of tunne 'feeling' (in line 2), at which her two companions, Karolina and Stina, burst out laughing. Hanna replaces the word with the Swedish equivalent känsla 'feeling' (in line 5).

All the interlocutors seem to be satisfied with this as the Finnish word tunne 'feeling' is not mentioned at all. Halmari uses the notion backtracking when referring to such instances where a started utterance is abruptly cut off and a switch into the other language follows ${ }^{28}$. In the end, Hanna still expresses unsecurity by saying en mä tiedä 'I don't know' in Finnish. There were several instances of hesitations and repeating of the phrase "I don't know" during the processes of

26 Ofelia García, "The translanguaging of Latino Kindergarteners", in Bilingual Youth. Spanish in English-speaking societies, K. Potowski and J. Rothman (ed.), Amsterdam, John Benjamins, 2011, p. 46.

27 H. Pardane, Kisno, Introduction to Sociolinguistics. From General to Local Perspectives, Jakarta Batam, LLC Publishing, 2012, p. 133.

28 Helena Halmari, Government and Code-switching. Expaining American Finnish (Studies in Bilingualism 12), Amsterdam - Philadelphia, John Benjamins, 1997, p. 57-58, 160. 
finding the right words in all three settings. This can be seen as an indicator of the difficulties in expressing oneself and finding words ${ }^{29}$.

(3) "tulee ihan erilainen tunnus" 'you get a totally different symbol'

\begin{tabular}{|c|c|}
\hline 01 Emma: & $\begin{array}{l}\text { mun iho tulee ihan semmonen kuivaks ja- } \\
\text { 'my skin gets totally like dry and-' }\end{array}$ \\
\hline 02 & $\begin{array}{l}\text { ((unintelligible)) tulee ihan erilainen tunnus tai- } \\
\text { 'you get a totally different symbol-' }\end{array}$ \\
\hline 03 Karolina: & $\begin{array}{l}\text { [个*tunnus* ((laughing) }) \\
\text { ‘symbol' }\end{array}$ \\
\hline 04 Stina: & {$[\uparrow *$ tunnus* $(($ laughing $))$} \\
\hline 05 Hanna: & erilainen känsla ja niinku- (.) \\
\hline 06 & $\begin{array}{l}\text { 'a different/ feeling/and like-' (Finnish/Swedish/Finnish) } \\
\text { en mä tiedä } \\
\text { 'I don't know' }\end{array}$ \\
\hline
\end{tabular}

\subsection{Expressing feelings, attitudes and evaluations}

Interjections are an important part of speech to express emotions, and bilingual adolescents use a lot of interjections from different language resources in their interaction with each other. Finnish is used for swearing and slang in all three language settings. The adolescents in Haparanda, Stockholm and Helsinki even use the same Finnish swear words, e.g. (voi) vittu '(oh) fuck' and mitä vittua 'what the fuck'. Finnish swear words in Swedish gives a slang effect and make Swedish sound tougher ${ }^{30}$. Also, monolingual Swedish-speaking adolescents in Haparanda use Finnish swear words, even though they otherwise don't use Finnish, because they find Finnish swear words emotionally satisfying ${ }^{31}$. Bilingual speakers may prefer Finnish swear words for emotional as well as pragmatic reasons ${ }^{32}$. For many speakers in Haparanda, Stockholm and Helsinki, Finnish is the language they use at home with their parents. Therefore, it is probably their emotional language. As one of the participants summit, "kun kotona tulee joku konflikti, käytämme suomea", 'when there is a conflict at home, we use Finnish'33.

29 See Niina Hynninen, Language Regulation in English as a Lingua Franca. Focus on Academic spoken discourse, Boston, De Gruyter, 2016, p. 115; Marja-Leena Sorjonen, Liisa Raevaara, "Asioimistilanteiden tutkimisesta: Tarkasteltavana Kelan asiointien vuorovaikutus", in Arjen asiointia. Keskusteluja Kelan tiskin äärellä, Helsinki, Suomen Kirjallisuuden Seura, 2006, p. 26.

30 See Leif Höckerstedt, "Helsingforssvenskan: vem är du?”, op. cit., p. 132.

31 Jaana Kolu, "Språkkontaktdrag i Haparandaungdomarnas muntliga och skrifliga kommunikation", in Svenskans beskrivning 31, A.-C. Edlund and I. Mellenius (ed.), Umeå, Umeå universitet, 2010, p. 161-169.

32 See Jean-Marc Dewaele, "Expressing Anger in Multiple Languages", in Bilingual Minds. Emotional Experience, Expression, and Representation, A. Pavlenko (ed.), Clevedon, Multilinual Matters, 2006, p. $118-151$.

33 See Jaana Kolu, "Språkkontaktdrag i Haparandaungdomarnas...", op. cit., p. 168-169. 
Switching between Finnish and Swedish or Finnish, Swedish and English probably has partly the same effect as slang in adolescents' interaction. Sprinkling Finnish words into a conversation basically in Swedish is very common in Helsinki, and Swedish- and Finnish-speaking adolescents share the same slang vocabulary ${ }^{34}$. In Stockholm the interlocutors more often use Swedish and English slang than Finnish, e.g. mää oon typ allerginen metsälle, 'I am /likel allergic to forest' (Finnish-Swedish-Finnish), jag bullshittade lite, 'I was /bullshitting/ a little' (Swedish-English-Swedish, I bullshit + Swedish ending for PRETERITE TENSE) eller "alla är sådana här /players/du vet", 'they are all such players you know' (Swedish-English-Swedish). The bilingual speakers in Stockholm and in Helsinki use more English than the adolescents in the rural town of Haparanda. Previous study of slang vocabulary in Haparanda and Helsinki showed that 11 percent of the slang vocabulary in Haparanda consisted of English words, whereas 20 percent of the slang vocabulary in Helsinki came from English ${ }^{35}$. Maybe the local aspect and the local words are more central for bilingual adolescents in Haparanda for expressing the local identity than for bilingual youth in Stockholm and Helsinki ${ }^{36}$. As mentioned above, Sweden Finns are quite a scattered minority in a multilingual milieu, whereas Swedish-speaking and bilingual adolescents in Helsinki use the same youth language and slang words than Finnish-speaking adolescents ${ }^{37}$. Apart from (standard) Finnish, Swedish and English the adolescents in Haparanda use words from Meänkieli and the local Finnish dialects, e.g. ruukata 'use to', festi 'party' and rasti 'break'. The adolescents in all three settings use a type of language which can be described as youth language, slang, and as a language with linguistic elements from different languages. It is important to remark that this is the language they use with their bilingual friends. It can be assumed that their language use is different with monolingual interlocutors.

In all three settings the interlocutors use English for emotive purposes, e.g. "nice" is a positive response to something another speaker has just said. The interlocutors mostly use short English phrases to express their attitudes, feelings and evaluations. When one of the participants in Haparanda is talking about his cousin, who got an old microcar from his friend (who turned eighteen and got a real car), his companion says: "se on aika true friendship", "it is rather/true

34 Jaana Kolu, "Allmängods och nykomlingar i svenskt ungdomsspråk och svensk slang", in Svenskan $i$ Finland 14, R. Kosunen, K. Lepistö and P. Rossi (ed.), Oulu, University of Oulu, Studia Humaniora Ouluensia 14, 2014, p. 115-125.

35 Ibid., p. 117, 121.

36 See Jaana Kolu, “Språkkontaktdrag i Haparandaungdomarnas...”, op. cit., p. 168-169; Johanna Vaattovaara, Meän tapa puhua. Torniojokilaakso pellolaisnuorten subjektiivisena paikkana ja murrealueena, Helsinki, Suomalaisen Kirjallisuuden Seura, 2009.

37 Jaana Kolu, "Allmängods och nykomlingar i svenskt ungdomsspråk och svensk slang", op. cit., p. 121. 
friendship' (Finnish-English). When one of the speakers says that he is going to be tested for cancer, the other one says: tänk på den här feelingen hon säger ba sulla on syöpä, 'think of that/feeling/she says like/you have cancer' (SwedishEnglish-Swedish-Finnish, think of that/feeling + SWEDISH ARTICLE (THE)/ she says like/you have cancer). It is possible that the use of different language resources makes it easier to express feelings on sensitive issues. According to Pardede and Kisno, "a speaker feels free and more comfortable to express their emotional feelings in a language that is not their everyday language". On the other hand, Pardede and Kisno assert that "Usually, when someone who is talking using a language that is not his native tongue suddenly wants to be emphatic about something he/she, either intentionally or unintentionally, will switch from his second language to his first language" ${ }^{\text {". }}$. In one conversation in Stockholm, three girls are talking in Swedish about boyfriends. When one of the girls, Ella, says that she believes that she will never get a boyfriend because she is not pretty enough, the other girl, Sara (who has Finnish as her mother tongue) switches to Finnish: "voi nyt perhana Ella olet sievempi kuin sana sievä itse" 'damn it Ella you are prettier than the word pretty itself". The third girl, Alice, who has difficulty expressing herself in Finnish, says in Swedish, du är faktiskt jättevacker, 'you are actually really beautiful'.

\subsection{Showing off one's language abilities and playing with one's language resources}

The English language appears to have high prestige among bilingual adolescents in all the three settings and the participants show off their abilities in English and in other languages. In two conversations, one of the interlocutors switches totally to English. In one conversation in Stockholm, two of the three speakers are cheerleaders. When they start talking about it, one of the girls switches to English. She is multilingual in Finnish, Swedish and English. It seems more natural for her to talk in English about the subject since all terms are in English. Also in Helsinki one of the speakers with a multilingual background switches to fluent English at one point in the conversation. All the other interlocutors use mainly single words or phrases in English, e.g. "sitten me aletaan puhumaan ihan random jutuista" (Finnish-English-Finnish), 'then we will start talking about totally/random/topics' and "tämä on aika fancy tämä" (Finnish-English-Finnish) 'this is quite a/ fancy/this'. There are also hybrid words, e.g. "det är jätteakward bara man ser det här" 'it is really/akward/ if you only see this' (Swedish-English). Some of the English words are integrated into Finnish, e.g. eikö ollukin aika fänssinen kynä, 'wasn't it quite a fancy pen' (Finnish-English-Finnish, wasn't it quite a fancy + vocal ' $i$ ' + Finnish ending for ADJ pen).

38 H. Pardane, Kisno, op. cit., p. 132-133. 
The participants also show their abilities in other languages, e.g. one participant in Stockholm thanks her schoolmate by saying in German: "Danke skön, meine Freundin", 'thank you my friend'. In example (4) below from Stockholm the participants, two girls and a boy, start playing with their different language resources and say disconnected phrases to each other.

(4) "just kidding förlåt Harri no offence men jag var tvungen att säga det" 'just kidding I am sorry Harri no offence but I had to say it'

\begin{tabular}{|l|l|}
\hline 01 Harri: & $\begin{array}{l}\text { iHola, mi compadre! } \\
\text { 'hi, pal' } \\
\text { hola hola hola } \\
\text { 'hello, hello, hello' } \\
\text { me ilamo pedro } \\
\text { 'my name is pedro' } \\
\text { je suis- } \\
\text { 'I am-' } \\
\text { Bonjour } \\
\text { 'hello' } \\
\text { je suis- } \\
05 \text { Mia: } \\
06 \text { Anna: }\end{array}$ \\
07 Anna: & $\begin{array}{l}\text { tu es folle } \\
\text { 'you are crazy' } \\
\text { just kidding förlåt Harri no offence men jag var tvungen att säga det }\end{array}$ \\
'just kidding/I am sorry Harri/no offence/but I had to say it' \\
((unintelligible) $)$
\end{tabular}

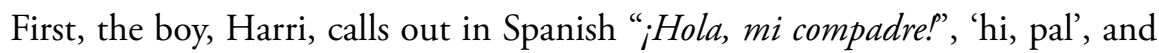
one of the girls, Anna, answers, “'Hola, hola, hola?”, 'hello, hello, hello'. That sets the ball rolling. Anna tries to start a sentence in French: je suis-, 'I am-', but the other girl, Mia, interrupts her by saying in French, Bonjour, 'hello'. In line 7 Anna says in French to Harri, "tu es folle", 'you are crazy' and they all start laughing. In 
line 8, Anna apologizes to Harri and says "just kidding förlåt Harri no offence men jag var tvungen att säga det, "just kidding/I am sorry Harri/no offence/but I had to say it' (English-Swedish-English-Swedish).

The girls repeat "tu es folle", you are crazy'. Then Anna changes the vowel to "tu es full", 'you are/drunk' (French-Swedish) and "tu es ful", 'you are/ugly' (FrenchSwedish). Finally Anna says "du är fåne” [fonع], 'you are a fool' (Swedish) and Mia continues du är telefon, 'you are a telephone' (Swedish). They are playing with words and sounds that rhyme in different languages. In line 10, Mia explains in Swedish to Harri that "det är typ samma sak" 'it is like the same thing' (Swedish). She probably means that "tu es folle", 'you are crazy' and "du är fåne" [fonc], 'you are a fool' mean the same thing.

English, Spanish and German words and phrases are used in the conversations in all three language settings. French is used only in Stockholm. The bilingual adolescents use their language repertoires playfully, but they use mostly single words or phrases in languages other than Finnish and Swedish. It can be assumed that the recording affected to some extent the participants' language use and their eagerness to show their language abilities when they were aware of my interest of their language use ${ }^{39}$.

\subsection{Co-constructing and organizing the interaction and marking boundaries in the continuous discourse}

In all of the conversations, the bilingual and multilingual adolescents use their language resources flexibly in order to organize and flag the borderlines between different parts of the interaction. This finding is identical to previous research ${ }^{40}$. For example, Maschler reports that discourse markers occurs at boundaries of units in bilingual conversations ${ }^{41}$. In Haparanda the Swedish discourse particle typ 'like' is used to signal the boundaries between Finnish and Swedish: "mää olin typ fem år då”, 'I was / like five years old then' (Finnish-Swedish). Also in Helsinki the interlocutors use discourse particles and pronouns to flag the switch from Swedish to Finnish: "ja har aldrig slått nåt annat än liksom nyrkkeilysäkkiä", 'I have never hit anything else but like/ a boxing punch bag' (Swedish-Finnish). Previous examinations have demonstrated that discourse particles can flag or precede switches into and quotes from another language ${ }^{42}$. According to Henricson

39 See Experimenter expectancy effect in A Dictionary of Psychology, A. M. Colman (ed.), Oxford, Oxford University Press, 2008.

40 Deborah Schiffrin, Discourse Markers, Cambridge, Cambridge University Press, 1987, p. 31; Yael Maschler, "Metalanguage and discourse markers in bilingual conversation", Language in Society, 23, 1994, p. 325-366; Yael Maschler, "What can bilinguals conversation tell us about discourse markers?: Introduction", International Journal of Bilingualism, 4(4), 2000, p. 437-445.

41 Ibid., p. 438.

42 Jim Hlavac, "Bilingual discourse markers: Evidence from Croatian-English code-switching", Journal of Pragmatics, 38 (11), 2006, p. 1870-1900. 
discourse markers serve as language-neutral bridges between the two languages, Swedish and Finnish ${ }^{43}$. Kolu suggests that discourse markers enables insertion of uninflected elements from Swedish into the morphosyntactic frame of Finnish when they precede embedded elements from Swedish ${ }^{44}$. Maschler concludes, "the verbalization of discourse markers is very often accompanied by the bilingual strategy of language alternation ${ }^{45}$.

The interlocutors are really creative when they arrange and co-construct multilingual interaction using their linguistic resources. For instance, in one conversation in Stockholm, where the participants speak alternately Swedish and Finnish, English is used for organizing the interaction. When the interlocutors change the subject, they spontaneously choose the next speaker, i.e., the person who has to be first to say something about the new subject, by using the game rock-paper-scissors in English ${ }^{46}$. In another group the three interlocutors speak Finnish and Swedish, but they change the subject by using English, e.g. "to next question". In the example (5) below a group of girls in Stockholm try to find the next topic for discussion. In line 3, Alice urges Fia to say something about her future by saying, okej Fia börjar talking. Before switching back to Swedish Fia says, okej about my future. Just like discourse markers, English phrases may serve as neutral links at the discourse boundaries in the conversations.

\section{(5) "okej about my future"}

\begin{tabular}{|c|c|}
\hline 01 Sara: & ooh mää tiiän mistä me voijjaan puhua- meän tulevaisuudesta \\
\hline 02 Fia: & $\begin{array}{l}\text { ei älä nytten mää nään vaan mustaa- mää en nää mittään- } \\
\text { 'no don't I see only black- I can't see anything-' }\end{array}$ \\
\hline 03 Alice: & $\begin{array}{l}\text { okej Fia börjar talking } \\
\text { 'okay Fia starts/talking' (Swedish-English) }\end{array}$ \\
\hline 04 & $\begin{array}{l}\text { nu tar jag bort dom här ((puts away some pens) } \\
\text { 'now I will take these away' }\end{array}$ \\
\hline 05 & Fia har den talking stick (Swedish-English) \\
\hline 4 Fia: & $\begin{array}{l}\text { 'Fia has the talking stick ((Fia is holding a pen as a microphone')) } \\
\text { okej about my future ((After that switches back to Swedish)) }\end{array}$ \\
\hline
\end{tabular}

43 Sofie Henricson, Svenska i finsk miljö. Interaktion, grammatik och flerspråkighet på svenska språköar $i$ Finland, Helsingfors, Helsingfors universitet, finska, finskugriska och nordiska institutionen, 2013.

44 Jaana Kolu, “Määhän aina niinku sekotan typ engelska svenska och finska'. Diskurspartiklar som interaktionell och grammatisk resurs i tvåspråkiga ungdomssamtal i Haparanda, Stockholm och Helsingfors", in Svenskans beskrivning 35, E. Sköldberg, H. Adamsson Eryd, M. Andreásson, F. Lindahl, S. Lindström, J. Prentice and M. Sandberg (ed.), Göteborg, Göteborgs universitet, 2017, p. 107-119.

45 Yael Maschler, "What can bilinguals conversation tell us about discourse markers?...", op. cit., p. 437-445.

46 It is a hand game in which each player simultaneously forms one of three shapes with an outstretched hand. 


\section{Conclusions}

Above, I have described bilingual adolescents' language use, linguistic resources, and communicative practices in interaction in Haparanda, Stockholm and Helsinki. This study has focused on translanguaging practices in Haparanda, but a comparison was made to the conversational data from Stockholm and Helsinki. The aim of this study is to increase our knowledge of bilingual adolescents' interaction practices, i.e. translanguaging. The analysis of bilingual adolescents' interaction in these three research settings reveals similar patterns and communicative practices in their use of multiple language resources, but the language settings impact on adolescents' translanguaging.

The adolescents translanguage in order to co-construct meaning and to make sense beyond the resources of any one particular language or language variety. Differences between the adolescents' communication are probably partly caused by the power and status of Finnish and Swedish in the surrounding society. In Haparanda, both Finnish and Swedish have an important role in society, because most of the population have a Finnish and bilingual background. Nevertheless, Swedish is a society-bearing language. In Stockholm, Swedish is a majority language while Finnish is a minority language. In Helsinki, these roles are reversed.

What is common to all interaction in the three settings is that adolescents translanguage, e.g. they switch languages to clarify, and translate, in order to negotiate meaning and gain mutual understanding. The adolescents quote a person in the original language or refer to culture-specific phenomena in the surroundings in the majority language. Additionally, they translanguage in order to express attitudes, emotions (e.g. slang) and solidarity with their interlocutors. Language resources are also used to organize and mark boundaries in the conversations. Discourse markers from both Swedish and Finnish are languageneutral elements which are used to mark boundaries. Language abilities are appreciated and creatively and effectively utilized by bilingual adolescents and they show off and play with their language repertoires. García claims that: "the most important language practice of bilinguals now and especially in the future is their ability to use language fluidly, to translanguage in order to make meaning beyond one or two languages" ${ }^{37}$. The Common European Framework of Reference for Languages also emphasizes that different languages can no longer be strictly separated in unrelated "corners" of the mind in our multilingual societies and in different social contexts, a person can flexibly utilize this competence to gain understanding with a interlocutor which may have different linguistic and

47 Ofelia García, "Theorizing translanguaging for educators", op. cit., p. 1-6. 
cultural background. For example, interlocutors may switch from one language to another, "exploiting the ability of each to express themselves in one language and to understand the other" ${ }^{38}$. Above all, bilinguals translanguage in order to reach mutual understanding and embrace their multiple language resources and bilingual identity.

48 Council of Europe. Common European framework of reference for languages: Learning, teaching, assessment, Cambridge, U.K: Press Syndicate of the, 2001. 